\title{
Feasibility research on the potential use of Migrant Workers Scan data to improve migration and population statistics
}

Amanda Sharfman, Victoria Staples, Helen Hughes

Office for National Statistics

\section{Abstract}

The ONS Centre for Demography is currently researching the use of a number of administrative data sources to improve population and migration statistics as part of the Inter-departmental Migration Statistics Improvement Programme. This article reports early findings from the initial research into one of the sources, the Migrant Workers Scan (MWS). The MWS contains information on all adult overseas nationals who have registered for, and been allocated, a National Insurance Number (NINo). The Department for Work and Pensions (DWP) supplied anonymised data to ONS on behalf of HM Revenue and Customs (HMRC) to further these investigations. 


\section{Contents}

Abstract 36

Introduction. 39

Overview of the Migrant Workers Scan. 39

Distributions from Migrant Workers Scan data. 41

Internal Moves 43

Lag between UK Arrival and NINo Registration. 47

Other Planned Analyses 49

Summary 50

Key points. 51

Acknowledgements 51

References 51

\section{List of figures}

Figure 1 Comparison of NINo arrivals ${ }^{1}$ in England and Wales with international migration ${ }^{2}$ inflows, mid 2006-mid $2007^{3}$

Figure 2 Comparison of local authority distributions of NINo arrivals ${ }^{1}$ in England and Wales and international migration ${ }^{2}$ inflows, mid-2006-mid-2007 ${ }^{3}$

Figure 3 Delay between arrival in the UK and NINo registration for men, women, married or other, January 2002-June 2006 .

Figure 4 Delay between arrival in the UK and NINo registration for adult overseas nationals arriving, January 2002-June 2006. 


\section{List of tables}

Table 1 Categorisation of internal moves of overseas nationals with NINo registrations, September 2007-June 2008

Table 2 Type of internal move made by adult overseas nationals with NINo registrations, September 2007-June 2008.

Table $3 \quad$ Origin and destination GOR for overseas nationals with NINo registration moving within or across GOR boundaries, September 2007-June 2008

Table 4a Proportion of overseas nationals with NINo registration moving across GOR boundaries, September 2007-June 2008

Table 4b Proportion of NHSCR inter-regional migration movements within the UK ${ }^{1}$, year ending June 2008

Table 5 Delay between arrival in the UK and NINo registration, January 2002-June 2006 .. 47

Table 6 GOR distribution of delay between arrival in the UK and NINo registration, January 2002-June 2006 


\section{Introduction}

In recent years the importance of migration as the main driver of population change has heightened the level of uncertainty in population estimation at both the national and local levels. The limitations of using survey sources to estimate migration statistics have been recognised and in a recent ONS exercise on statistical priorities this was the area which users saw as the highest priority for seeking improvements.

The ONS Centre for Demography (ONSCD) produces population estimates using a cohort component methodology. This methodology uses Census data as a baseline which is then aged on each year before adjustments are made for births, deaths, internal migration and international migration. Internal migration is estimated using changes in General Practitioner (GP) patient registrations and international migration is principally estimated using the International Passenger Survey (IPS). Improved information on migrants is a priority to help improve population estimates, projections and indicators, as well as to support central and local government resource allocation, service planning and delivery.

In May 2006, ONS set up an Inter-departmental Task Force on Migration Statistics ${ }^{1}$ to consider improvements that could be made to estimates of migration and migrant populations in the UK. One of the key recommendations related to making better use of data from a number of administrative sources. More recently, in May 2008, the Treasury Select Committee report 'Counting the Population'2 recommended that the UK Statistics Authority should continue the work by ONS to identify alternative administrative data sources for use in migration and population statistics.

As a result of these recommendations, ONSCD is investigating a number of administrative sources including School Census, Higher Education Statistics Agency (HESA) and Department for Work and Pensions (DWP) data to understand better each administrative source and determine whether they can be used to improve migration and population statistics. An initial report on progress in this area, specifically relating to DWP data sources, was published in May $2009^{3}$. The report provided an overview of the potential DWP sources and proposed a number of avenues for further investigation. The MWS was identified as an administrative source with the potential to deliver improvements. Research since this initial report has focussed on further investigation of anonymised MWS data, obtained under an existing legal gateway to data sharing. DWP has supplied data extracts to ONS on behalf of HMRC. An initial feasibility report on the usefulness of these data was published in October $2009^{4}$. Preliminary findings from the analysis of these MWS data are reported in this paper. These include:

- demographic and geographic distributions

- identification of onward moves by overseas nationals from successful linkage between extracts

- investigation of the time difference between an individual arriving in the UK and registering for a National Insurance Number (NINo)

\section{Overview of the Migrant Workers Scan}

The MWS is a subset of data from the National Insurance Recording System (NIRS-2). This subset includes all adult overseas nationals (non-UK citizens) who have registered for, and been allocated, a NINo in order to work legally or claim benefits. Migrant groups not covered by the 


\section{Box one UN definition of an international long-term migrant}

A person who moves to a country other than that of his or her usual residence for a period of at least a year (12 months), so that the country of destination effectively becomes his or her new country of usual residence. From the perspective of the country of departure, the person will be a long-term emigrant and from that of the country of arrival, the person will be a long-term immigrant.

MWS include child migrants (those under 15 years 9 months), migrants who work illegally, and adult migrants who neither work nor claim benefits (commonly students or spouses of employed migrants). Asylum seekers are also generally excluded as NINo applications are not usually approved until rights to reside in the UK have been granted.

The MWS does not hold any information on length of stay as there is no requirement to de-register when returning overseas. An overseas national may arrive in the UK, register for a NINo and work for a short period before returning overseas, while others may arrive and delay registering for some time. Individuals in MWS data are referred to here as 'overseas nationals with NINo registrations' rather than migrants as they do not necessarily fit the UN definition of a long-term migrant used by the ONS (see Box one). Therefore, these data are not directly comparable with ONS international immigration estimates.

DWP publish National Statistics on NINo allocations to adult overseas nationals, with aggregate data available via its tabulation tool. These statistics are currently reported by calendar and financial year of registration ${ }^{5}$.

Aggregate outputs from the DWP tabulation tool were used in an initial assessment of the scope, content and quality of the MWS. Following this initial assessment, workshops and discussions between ONS and DWP, ONS was able to gain access to anonymised personal data from the MWS.

DWP supplied three extracts from the MWS. These include registrations from 1975 to 24 September 2007, 31 December 2007 and 8 June 2008. Migrant records are cumulative: therefore later extracts contain all registrations included in previous extracts. ONSCD has only used registrations since 1 January 2002, as recommended by DWP. The data items provided for the initial feasibility research are listed in Box two.

The MWS provides high coverage of migrant workers, has national coverage and is considered a high quality data source. However, a number of limitations associated with using this administrative data source for ONS's statistical purposes have been identified through initial data quality investigations:

- under coverage - not all migrants receive a NINo, thus some migrants are not included in these data

- over coverage - no indication if migrant has left the UK, thus those who are not in the UK are included

- definition of a migrant - differs between ONS and that available from the MWS, thus there is no direct comparison 


\section{Box two Variables in Migrant Workers Scan}

Address (including postcode)

Date of birth

Age at extract (derived)

Gender

Nationality

Country of origin (previous country of residence)

Date of arrival

Date of registration

Date of death

Address indicator

Encrypted NINo (derived by DWP)

Geographic referencing variables (including LA and GOR derived by DWP)

Date of extract (derived at download)

- addresses - can be out of date or are not residential, thus some location data are inaccurate

- country of previous origin - has a high number of invalid records thus this variable is not suitable for further analysis

- upper age - bias as data are often not updated if migrants die abroad thus statistical adjustment is required

The quality of these data and most variables do provide a reliable basis for analysis. These limitations are statistical, and do not impact on the administrative uses of these data.

\section{Distributions from Migrant Workers Scan data}

As previously noted, the definition of a migrant differs between ONS and the MWS, meaning that no direct comparison can be made. To ensure as close a comparison as possible, a subset of the international migration component of population change has been used. This includes all international immigrants aged 15 and over with the exception of Asylum Seekers.

The age distribution of overseas nationals with NINo registrations arriving in the UK between July 2006 and June 2007 is shown in Figure 1, compared to the age distribution in the mid-2007 international migration component of change data (excluding asylum seekers). There is generally good agreement between the age distributions. A notable area of divergence is the 15-19 age group. Differences in the 15-19 age group may be related to international students and the fact that only a proportion of those aged 15 will be covered in the MWS. The MWS records a greater proportion in the 25-34 age groups. These differences may relate to short-term migrants who are typically young ${ }^{6}$, or international students who remain in the country to work. 


\section{Figure 1 Comparison of NINo arrivals ${ }^{1}$ in England and Wales with international migration ${ }^{2}$ inflows, mid 2006-mid $2007^{3}$}

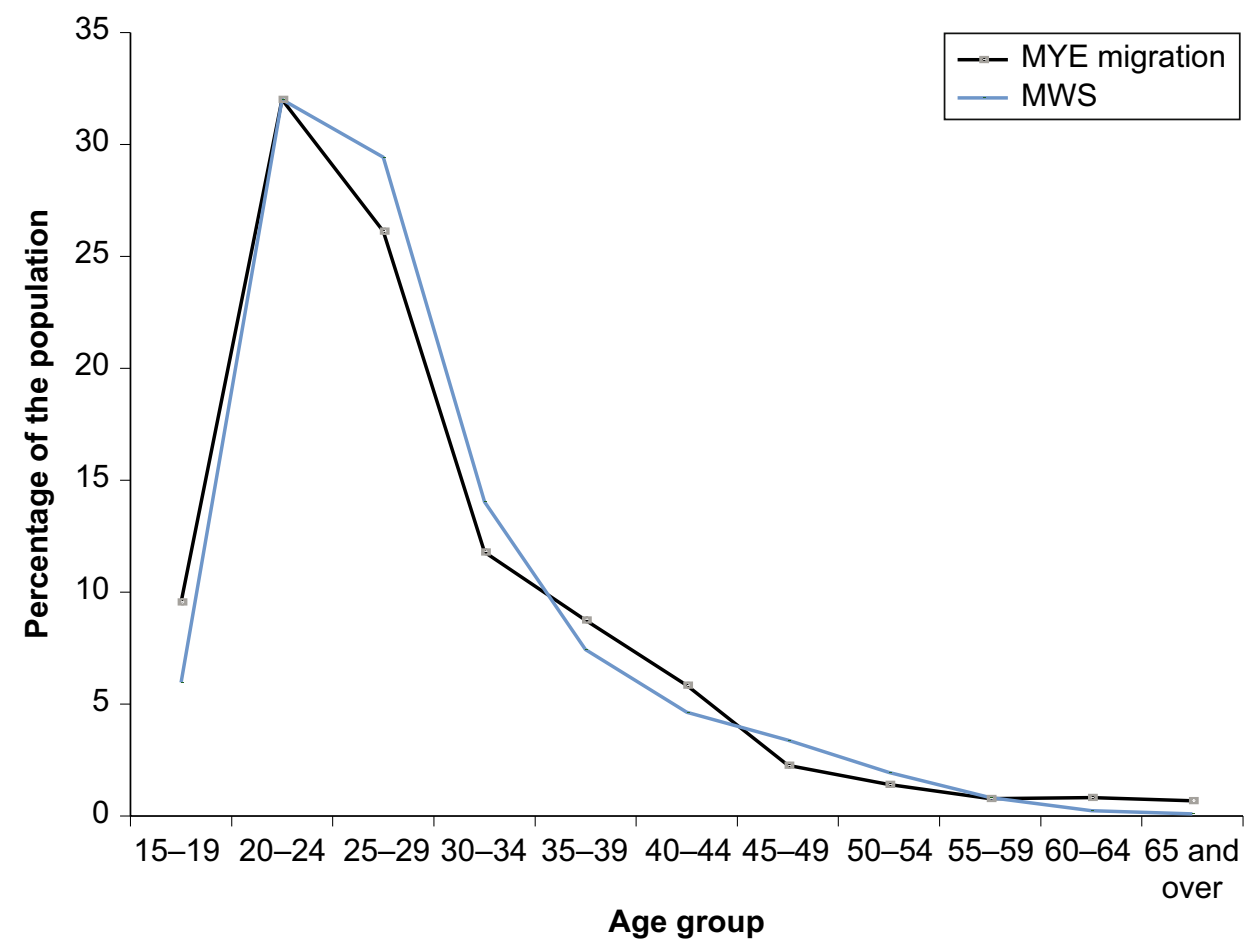

Notes:

1 NINo arrivals include adult overseas nationals arriving in the UK mid-2006 to mid-2007 and registering before 8 June 2008, whose address at extract is within England and Wales

2 International Migration data presented here exclude asylum seekers

3 Data published August 2009

Sources: Migrant Workers Scan extract 1 January 2002-8 June 2008; Mid-2007 International migration

Figure 2 shows a comparison of the geographical distributions of NINo registrations at LA level compared to the international migration components of the mid-2007 population estimates (excluding asylum seekers). There are marked differences in the distributions. Areas with large student populations, such as Leeds and Cambridge, receive a greater proportion of migrants in the international migration data compared to the MWS data. A potential reason for some areas receiving a greater proportion of migrants in the MWS may be the inclusion of short-term migration. This demonstrates the different geographical distributions of disparate migrant sub-populations. Aggregate MWS data are already included in improved methodologies to model migrants at LA level.

These and other local distributions at LA and Government Office Region (GOR) level, such as the number of male and female overseas nationals with NINo registrations resident in each age group, are examples of distributions that could be used in methodologies under development to improve internal and international migration estimates, population statistics, and quality assurance. 
Figure 2 Comparison of local authority distributions of NINo arrivals ${ }^{1}$ in England and Wales and international migration ${ }^{2}$ inflows, mid-2006-mid-2007³

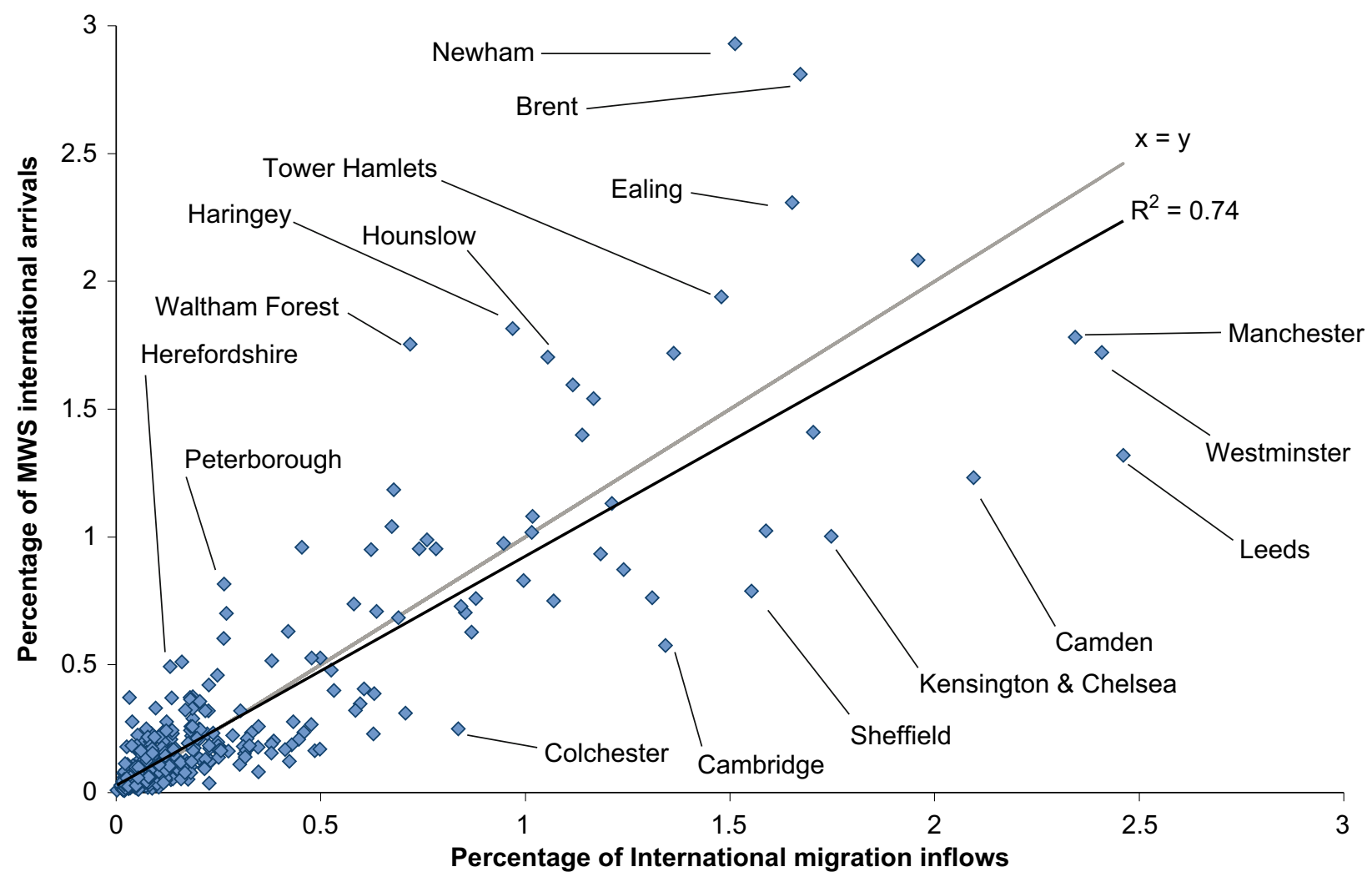

Notes:

1 NINo arrivals include adult overseas nationals arriving in the UK mid-2006 to mid-2007 and registering before 8 June 2008, whose address at extract is within England and Wales

2 International Migration data presented here exclude asylum seekers

3 Data published August 2009

Sources: Migrant Workers Scan extract 1 January 2002-8 June 2008; Mid-2007 population estimates component data

\section{Internal Moves}

Overseas nationals provide address information when registering for a NINo at a Jobcentre Plus, but changes in address are only updated on NIRS-2 if HMRC is informed of a change. Anecdotally, this is most likely to happen for overseas nationals who are self-employed and must complete a tax return or those claiming benefits. The address information for those who move and do not inform HMRC will therefore be out of date. Some addresses may also be non-residential. Record linkage of successive MWS extracts has been used to determine if this data source can effectively capture internal moves of overseas nationals with NINo registrations.

The three MWS extracts were successfully linked using the unique encrypted NINo identifier associated with every record. Internal moves in the period between the first and third extract (24 September 2007 to 8 June 2008) were captured by comparing postcodes, local authority codes and GOR codes. Only records with a valid postcode in both extracts (84 per cent) were included when identifying an internal move. A change in valid postcode was defined as an internal move and 


\section{Table $1 \quad$ Categorisation of internal moves of overseas nationals with} NINo registrations, September 2007-June 2008

\begin{tabular}{lll}
\hline Category & Type of Internal Move & Description \\
\hline 1 & No postcode move & Valid postcodes remained the same between extracts \\
2 & Within local authority and within GOR & Valid postcode change with no change in LA or GOR \\
3 & Across local authorities and within GOR & Valid postcode change with change in LA within the same GOR \\
4 & Across local authorities and across GOR & Valid postcode change across LA and GOR boundaries \\
\hline
\end{tabular}

categorised into types of move as shown in Table 1. Migrants who have subsequently left the UK could be included in all categories.

Within the eight month period between the first and third MWS extracts, postcode moves were identified for almost 18 per cent of overseas nationals with valid postcodes in both extracts (Table 2). Over a 12 month period it is estimated that up to 25 per cent of MWS records with valid postcodes may be identified as internal moves using this method. There were around eight per cent 'across local authority' moves, with 40 per cent of these also moving across GOR boundaries.

\section{Table $2 \quad$ Type of internal move made by adult overseas nationals with NINo registrations, September 2007-June 2008}

\begin{tabular}{llrr}
\hline Category & Type of internal move & $\begin{array}{r}\text { Frequency } \\
\text { (thousands) }\end{array}$ & Percentage \\
\hline 1 & No internal move & $2,198.7$ & 82.3 \\
2 & Within LA and within GOR & 257.4 & 9.6 \\
3 & Across LA and within GOR & 129.6 & 4.9 \\
4 & Across LA and across GOR & 85.2 & 3.2 \\
& Total & $\mathbf{2 , 6 7 0 . 9}$ & $\mathbf{1 0 0}$ \\
\hline
\end{tabular}

Source: Migrant Workers Scan extract 1 January 2002-8 June 2008

Overseas nationals with NINo registrations resident in London made 155,340 internal moves between London boroughs in the period between September 2007 and June 2008 (Table 3). This was three times as many internal moves as within any other GOR. Internal moves between GORs were highest between London and the South East and East of England, with net movement out of London into each of these regions.

Table $\mathbf{4 a}$ and $\mathbf{4 b}$ show the proportion of moves from each origin GOR into each destination GOR from the MWS and National Health Service Central Register (NHSCR) respectively. These tables indicate markedly different patterns of movement. The MWS shows a much greater proportion of moves into London compared to the NHSCR. For example, 48 per cent of overseas nationals with NINo registrations moving out of the South East went to London compared to 28 per cent of NHSCR re-registrations. It is interesting to note that there is a considerably greater amount of movement between non-contiguous GORs in the MWS data. For example, 32 per cent of moves from the South West are to London in the MWS data compared to 16 per cent in the NHSCR data. 


\section{Table $3 \quad$ Origin and destination GOR for overseas nationals with NINo registration moving within or across GOR boundaries, September 2007-June 2008}

\begin{tabular}{|c|c|c|c|c|c|c|c|c|c|c|c|c|c|}
\hline \multirow[b]{2}{*}{$\begin{array}{l}\text { Origin } \\
\text { GOR }\end{array}$} & \multicolumn{13}{|c|}{ Destination GOR } \\
\hline & $\begin{array}{l}\text { North } \\
\text { East }\end{array}$ & $\begin{array}{l}\text { North } \\
\text { West }\end{array}$ & $\begin{array}{c}\text { Yorkshire } \\
\text { and the } \\
\text { Humber }\end{array}$ & $\begin{array}{c}\text { East } \\
\text { Midlands N }\end{array}$ & $\begin{array}{r}\text { West } \\
\text { Midlands }\end{array}$ & $\begin{array}{r}\text { East } \\
\text { England }\end{array}$ & London & $\begin{array}{l}\text { South } \\
\text { East }\end{array}$ & $\begin{array}{l}\text { South } \\
\text { West }\end{array}$ & Wales & Scotland & $\begin{array}{l}\text { Northern } \\
\text { Ireland }\end{array}$ & Total \\
\hline North East & 5,840 & 200 & 240 & 130 & 160 & 120 & 590 & 240 & 100 & 50 & 210 & 20 & 7,900 \\
\hline North West & 200 & 27,680 & 840 & 490 & 740 & 500 & 1,820 & 810 & 400 & 280 & 430 & 100 & 34,290 \\
\hline $\begin{array}{l}\text { Yorkshire } \\
\text { and the } \\
\text { Humber }\end{array}$ & 220 & 810 & 22,800 & 620 & 620 & 450 & 1,400 & 660 & 310 & 140 & 330 & 60 & 28,420 \\
\hline $\begin{array}{l}\text { East } \\
\text { Midlands }\end{array}$ & 100 & 430 & 580 & 22,370 & 840 & 740 & 1,450 & 740 & 340 & 130 & 290 & 50 & 28,060 \\
\hline $\begin{array}{l}\text { West } \\
\text { Midlands }\end{array}$ & 130 & 660 & 540 & 840 & 26,240 & 590 & 1,920 & 1,020 & 580 & 290 & 400 & 60 & 33,270 \\
\hline $\begin{array}{l}\text { East } \\
\text { England }\end{array}$ & 110 & 440 & 460 & 1,000 & 550 & 28,430 & 3,690 & 1,580 & 520 & 160 & 350 & 90 & 37,380 \\
\hline London & 340 & 1,530 & 1,170 & 1,380 & 1,660 & 5,1101 & 155,340 & 7,430 & 1,610 & 480 & 1,230 & 180 & 177,460 \\
\hline South East & 160 & 630 & 560 & 760 & 860 & 1,480 & 6,330 & 42,320 & 1,380 & 290 & 560 & 100 & 55,430 \\
\hline South West & 70 & 330 & 240 & 290 & 530 & 470 & 1,770 & 1,270 & 19,680 & 240 & 280 & 50 & 25,220 \\
\hline Wales & 50 & 350 & 160 & 140 & 290 & 200 & 680 & 400 & 330 & 7,930 & 150 & 30 & 10,710 \\
\hline Scotland & 160 & 450 & 300 & 250 & 310 & 370 & 1,380 & 640 & 360 & 110 & 23,310 & 90 & 27,730 \\
\hline $\begin{array}{l}\text { Northern } \\
\text { Ireland }\end{array}$ & 30 & 100 & 60 & 70 & 60 & 100 & 210 & 130 & 50 & 40 & 120 & 8,210 & 9,180 \\
\hline Total & 7,410 & 33,610 & 27,950 & 28,340 & 32,860 & 38,5601 & 176,580 & 57,240 & 25,660 & 10,140 & 27,660 & 9,040 & 475,050 \\
\hline
\end{tabular}

Source: Migrant Workers Scan extract 1 January 2002-8 June 2008

The successful record linkage between MWS extracts and the volume of internal migration moves that ONSCD was able to identify suggest that this data source is potentially of great value. Initial comparisons with NHSCR data have revealed differing patterns of movement. Further research on internal moves by overseas nationals with NINo registrations would help to understand patterns of migrant movement to inform future improvements to the local distribution of these migrants.

Comparison of flows captured in the MWS with other sources of information on migrants could also lead to adjustment of migration estimates. It is more likely that overseas nationals who are self-employed or claiming any type of benefit will inform HMRC of changes in address. Therefore, there is potential for underestimation and bias in the capture of internal moves by the MWS.

ONSCD will investigate the use of distributions of internal moves, rather than total counts derived from the MWS, in order to overcome any underestimation; however, this will not overcome the potential bias. 
Table $4 a$ Proportion of overseas nationals with NINo registration moving across GOR boundaries, September 2007-June 2008

Percentages

\begin{tabular}{|c|c|c|c|c|c|c|c|c|c|c|c|c|}
\hline Origin GOR & $\begin{array}{r}\text { North } \\
\text { East }\end{array}$ & $\begin{array}{l}\text { North } \\
\text { West }\end{array}$ & $\begin{array}{r}\text { Yorkshire } \\
\text { and the } \\
\text { Humber }\end{array}$ & $\begin{array}{r}\text { East } \\
\text { Midlands }\end{array}$ & $\begin{array}{r}\text { West } \\
\text { Midlands }\end{array}$ & $\begin{array}{r}\text { East } \\
\text { England }\end{array}$ & London & $\begin{array}{r}\text { South } \\
\text { East }\end{array}$ & $\begin{array}{l}\text { South } \\
\text { West }\end{array}$ & Wales & Scotland & $\begin{array}{r}\text { Northern } \\
\text { Ireland }\end{array}$ \\
\hline North East & - & 10 & 12 & 6 & 8 & 6 & 29 & 12 & 5 & 2 & 10 & 1 \\
\hline North West & 3 & - & 13 & 7 & 11 & 8 & 28 & 12 & 6 & 4 & 7 & 2 \\
\hline $\begin{array}{l}\text { Yorkshire and } \\
\text { the Humber }\end{array}$ & 4 & 14 & - & 11 & 11 & 8 & 25 & 12 & 6 & 2 & 6 & 1 \\
\hline East Midlands & 2 & 8 & 10 & - & 15 & 13 & 25 & 13 & 6 & 2 & 5 & 1 \\
\hline West Midlands & 2 & 9 & 8 & 12 & - & 8 & 27 & 15 & 8 & 4 & 6 & 1 \\
\hline East England & 1 & 5 & 5 & 11 & 6 & - & 41 & 18 & 6 & 2 & 4 & 1 \\
\hline London & 2 & 7 & 5 & 6 & 8 & 23 & - & 34 & 7 & 2 & 6 & 1 \\
\hline South East & 1 & 5 & 4 & 6 & 7 & 11 & 48 & - & 11 & 2 & 4 & 1 \\
\hline South West & 1 & 6 & 4 & 5 & 10 & 8 & 32 & 23 & - & 4 & 5 & 1 \\
\hline Wales & 2 & 13 & 6 & 5 & 10 & 7 & 24 & 14 & 12 & - & 5 & 1 \\
\hline Scotland & 4 & 10 & 7 & 6 & 7 & 8 & 31 & 14 & 8 & 2 & - & 2 \\
\hline $\begin{array}{l}\text { Northern } \\
\text { Ireland }\end{array}$ & 3 & 10 & 6 & 7 & 6 & 10 & 22 & 13 & 5 & 4 & 12 & - \\
\hline
\end{tabular}

Source: Migrant Workers Scan extract 1 January 2002-8 June 2008

\section{Table 4b Proportion of NHSCR inter-regional migration movements within the UK ${ }^{1}$, year ending June 2008}

Percentages

\begin{tabular}{|c|c|c|c|c|c|c|c|c|c|c|c|c|}
\hline Origin GOR & $\begin{array}{r}\text { North } \\
\text { East }\end{array}$ & $\begin{array}{l}\text { North } \\
\text { West }\end{array}$ & $\begin{array}{r}\text { Yorkshire } \\
\text { and the } \\
\text { Humber }\end{array}$ & $\begin{array}{r}\text { East } \\
\text { Midlands }\end{array}$ & $\begin{array}{r}\text { West } \\
\text { Midlands }\end{array}$ & $\begin{array}{r}\text { East } \\
\text { England }\end{array}$ & London & $\begin{array}{r}\text { South } \\
\text { East }\end{array}$ & $\begin{array}{l}\text { South } \\
\text { West }\end{array}$ & Wales & Scotland & $\begin{array}{r}\text { Northern } \\
\text { Ireland }\end{array}$ \\
\hline North East & - & 14 & 23 & 7 & 6 & 7 & 13 & 10 & 5 & 2 & 11 & 1 \\
\hline North West & 6 & - & 18 & 9 & 12 & 6 & 12 & 10 & 8 & 9 & 8 & 2 \\
\hline $\begin{array}{l}\text { Yorkshire and } \\
\text { the Humber }\end{array}$ & 10 & 18 & - & 19 & 8 & 8 & 12 & 10 & 6 & 3 & 6 & 1 \\
\hline East Midlands & 3 & 9 & 16 & - & 14 & 14 & 12 & 14 & 9 & 3 & 4 & 1 \\
\hline West Midlands & 2 & 12 & 8 & 16 & - & 7 & 13 & 13 & 15 & 9 & 4 & 1 \\
\hline East England & 2 & 6 & 7 & 14 & 6 & - & 25 & 23 & 10 & 3 & 4 & 1 \\
\hline London & 2 & 5 & 4 & 5 & 5 & 26 & - & 38 & 9 & 2 & 3 & 1 \\
\hline South East & 2 & 6 & 5 & 8 & 7 & 13 & 28 & - & 22 & 4 & 4 & 1 \\
\hline South West & 2 & 7 & 5 & 6 & 11 & 8 & 16 & 30 & - & 10 & 4 & 1 \\
\hline Wales & 2 & 16 & 5 & 6 & 15 & 6 & 11 & 14 & 20 & - & 4 & 1 \\
\hline Scotland & 8 & 14 & 9 & 6 & 6 & 8 & 15 & 14 & 9 & 4 & - & 6 \\
\hline $\begin{array}{l}\text { Northern } \\
\text { Ireland }\end{array}$ & 7 & 19 & 7 & 5 & 6 & 7 & 11 & 11 & 6 & 4 & 17 & \\
\hline
\end{tabular}

1 Based on patients re-registering with NHS doctors in other parts of the United Kingdom

Source: National Health Service Central Register; General Register Office for Scotland; Northern Ireland Statistics and Research Agency 


\section{Lag between UK Arrival and NINo Registration}

There is known to be a lag between arrival in the UK and NINo registration, in the same way that there is a delay in people moving to a new area and registering with a GP. The timing of data extracts used in estimating migration and population statistics is, therefore, an important factor in the coverage they are able to offer. This lag is considered in more detail to show how MWS data are affected by such delays.

The lag between arrival and registration has been investigated by calculating the period between these dates as recorded in the MWS (Table 5). There were very few overseas nationals registering for a NINo prior to arrival in the UK (0.2 per cent ). These could be re-arrivals as individuals may enter the UK, register for a NINo and subsequently leave the country, returning at a later date and informing HMRC of their re-arrival. There is, however, no requirement to do this. More than half (53.9 per cent) of NINo registrations occurred within the first six months of arrival and three quarters (75.2 per cent ) registered within a year of arrival in the UK.

\section{Table 5 Delay between arrival in the UK and NINo registration, January 2002-June 2006}

\begin{tabular}{lrrr}
\hline $\begin{array}{l}\text { Delay between UK arrival } \\
\text { and NINo registration }\end{array}$ & $\begin{array}{r}\text { Frequency } \\
\text { (thousands) }\end{array}$ & Percentage & $\begin{array}{r}\text { Cumulative } \\
\text { percentage }\end{array}$ \\
\hline Prior to arrival & 6.7 & 0.2 & 0.2 \\
0-3 months & 902.7 & 26.1 & 26.3 \\
3-6 months & 954.4 & 27.6 & 53.9 \\
6-9 months & 461.4 & 13.3 & 67.2 \\
9-12 months & 276.1 & 8.0 & 75.2 \\
12-18 months & 316.1 & 9.1 & 84.3 \\
18-24 months & 161.7 & 4.7 & 89.0 \\
More than 2 years & 379.6 & 11.0 & 100.0 \\
Total & $\mathbf{3 , 4 5 8 . 6}$ & $\mathbf{1 0 0}$ & - \\
\hline
\end{tabular}

Source: Migrant Workers Scan extract 1 January 2002 - 8 June 2008

There are differences in the distribution of this lag between arrival and NINo registration between men, married women and non-married women ${ }^{7}$. A greater proportion of non-married women registered within six months of arrival in the UK compared with married women (Figure 3).

There has also been a shift towards a shorter time lag (less than six months) between arrival and registration during 2002/03 to 2005/06 (Figure 4). One fifth of overseas nationals registering for a NINo in 2002/03 registered within six months of arrival; by 2005/06 over half registered within six months, which could be related to an increase in short-term migrants. More recent extracts would be required to understand the effect migrants from $A 8^{8}$ countries have had on the lag between arrival and registration over a longer time period.

The proportion of overseas nationals waiting over a year after arrival to register for a NINo was highest in London (30.2 per cent ; see Table 6). Further research is needed to identify what is causing these differences; for example, students registering after completion of courses that may be over a year in duration, or from other migrant types, e.g. asylum seekers. 
Figure 3 Delay between arrival in the UK and NINo registration for men, women, married or other, January 2002-June 2006

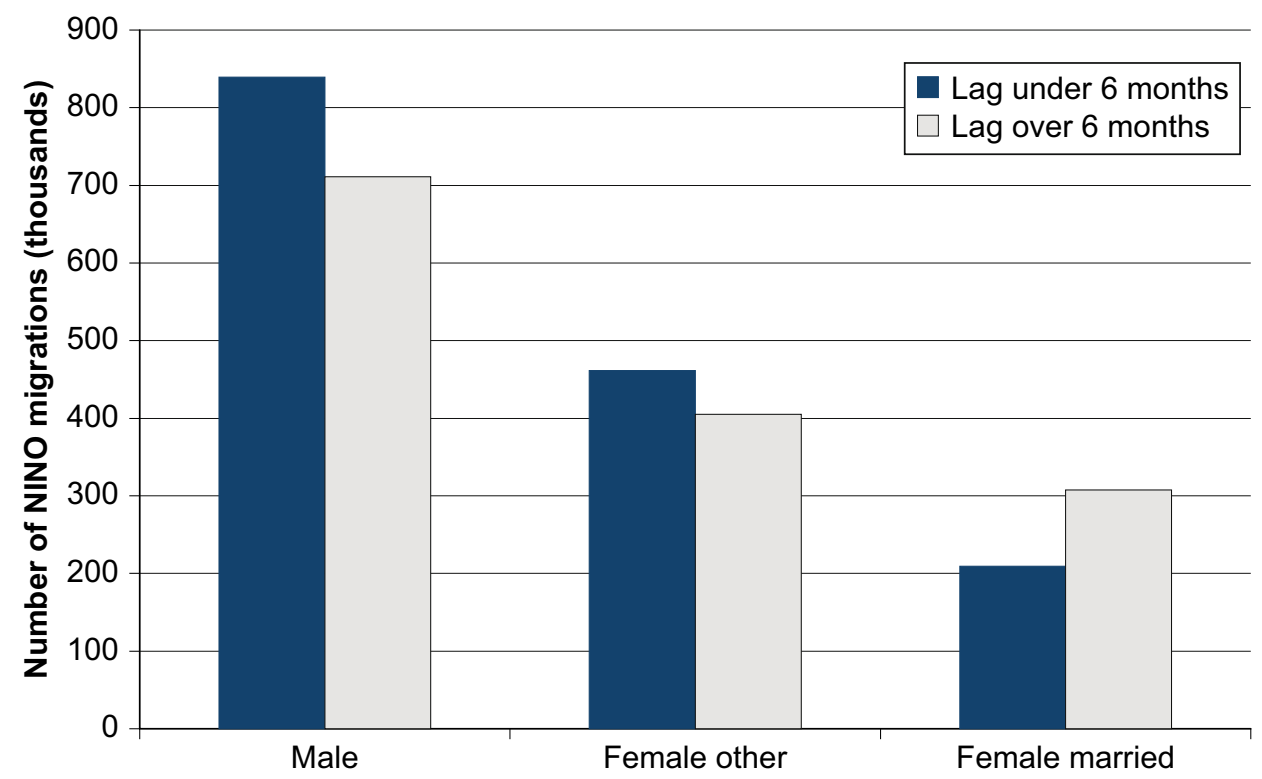

Source: MWS extract 1 January 2002-8 June 2008

Figure 4 Delay between arrival in the UK and NINo registration for adult overseas nationals arriving, January 2002-June 2006

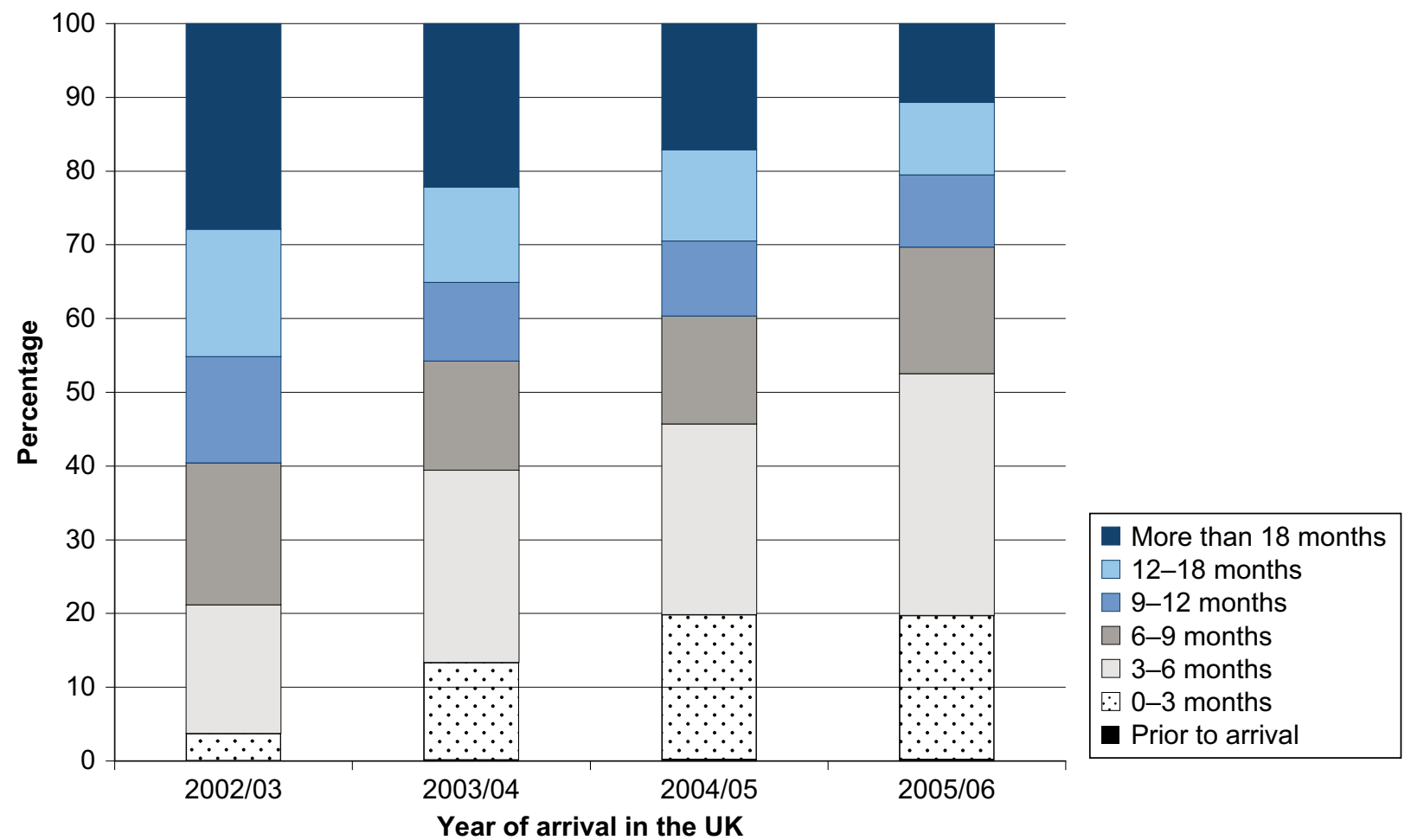

Note: the 'prior to arrival' category is not perceivable in the chart however has been included for consistency with table 5 Source: MWS extract 1 January 2002-8 June 2008 


\section{Table $6 \quad$ GOR distribution of delay between arrival in the UK and NINo registration, January 2002-June 2006}

\begin{tabular}{|c|c|c|c|}
\hline \multirow[b]{3}{*}{ GOR } & \multicolumn{3}{|c|}{ Delay between UK arrival and NINo registration } \\
\hline & \multicolumn{2}{|c|}{ Frequency (thousands) } & \multirow{2}{*}{$\begin{array}{r}\text { Percentage } \\
\text { Ove } \\
12 \text { months }\end{array}$} \\
\hline & $\begin{array}{l}\text { Under } \\
12 \text { months }\end{array}$ & $\begin{array}{r}\text { Over } \\
12 \text { months }\end{array}$ & \\
\hline North East & 22.4 & 6.3 & 22.0 \\
\hline North West & 100.1 & 22.5 & 18.4 \\
\hline Yorkshire and the Humber & 70.9 & 22.7 & 24.3 \\
\hline East Midlands & 76.6 & 17.2 & 18.4 \\
\hline West Midlands & 87.9 & 25.2 & 22.3 \\
\hline East England & 107.8 & 28.2 & 20.7 \\
\hline London & 447.9 & 193.4 & 30.2 \\
\hline South East & 160.2 & 47.8 & 23.0 \\
\hline South West & 73.2 & 18.7 & 20.4 \\
\hline Wales & 32.3 & 7.3 & 18.4 \\
\hline Scotland & 83.4 & 16.9 & 16.9 \\
\hline Northern Ireland & 27.9 & 8.8 & 23.9 \\
\hline
\end{tabular}

Source: MWS extract 1 January 2002-8 June 2008

Understanding of the lag between arrival in the UK and registration for a NINo in the MWS has been used to form assumptions used in the improved methods for migration and population statistics.

For example, an estimate of the number of overseas nationals who arrive and delay registration for a NINo by three years has been used in combination with HESA data to estimate the proportion of undergraduate students who are overseas nationals that stay in the UK to work after completing their studies. This information has been used in the improvements to the methodology to estimate students incorporated into the release of improved population estimates in May 2010. Information on these improvements is available from the ONS website ${ }^{9}$.

Research has shown that in order to cover 75 per cent of NINo registrations to overseas nationals, MWS extracts taken at least a year later than the arrival year of interest would be needed. The timeliness (quarterly) would need to be assessed against the coverage of this data.

\section{Other Planned Analyses}

Further exploratory analyses are underway to establish how ONS can use MWS data for population and migration estimation. These analyses include work to ascertain the feasibility of linking MWS data to other administrative data and survey sources and further comparisons of MWS data with combined estimates of short and long term migration, which would provide more meaningful comparisons.

The feasibility of matching and linking MWS data to patient register data has recently commenced. Patient register data are currently used to produce estimates of internal migration. Successful 
linkage of these two data sources could provide information on where those migrants still resident in the UK are living; however, there is no requirement to deregister from either source, thus it would not be possible to confirm UK residence. This matching process is not straightforward as the unique identifiers are different.

In order to gain maximum statistical benefits from the MWS, these data could be linked with other administrative sources. Linking data may provide more current address information. Possible data sources currently under review are: DWP's Work and Pensions Longitudinal Study (WPLS) - Master Index and Address History File, and extending the use of HMRCs ten per cent NIRS-2 sample that ONS already receives for business statistics.

These administrative sources contain the unique NINo identifier, which would make the matching and linking process between these sources and the MWS more straightforward. The matching process with administrative data sources from departments other than HMRC and DWP may be more complex.

The ONS Longitudinal Study (LS) is a set of linked, unidentifiable census and administrative records dating from 1971. Data matching is achieved through an intermediate source, the NHS Central Register, and uses name. The LS includes a one per cent representative sample of the population of England and Wales and could be used to quality assure MWS data and contribute to understanding the internal migration and duration of stay for migrants. Linkage of MWS data to the LS would be improved if MWS names as well as sex, date of birth and address were available. Any proposed linkage would require approval from the LS Steering Group.

There are also survey sources that could potentially be linked with MWS data, such as elements of the ONS Integrated Household Survey. The outcome of the feasibility work with patient registration data will inform whether linkage with these survey sources will be possible in the future.

\section{Summary}

The preliminary findings from initial feasibility studies reported here indicate that anonymised MWS data are potentially useful in developing methodologies to improve migration and population statistics. Data familiarisation has shown the MWS to be a high quality data source, providing a high national coverage of migrant workers. Further research is required to gain a better understanding of how these data can be used.

Aggregate data are already used in models for estimating long and short term migration. Understanding of the lag between arrival in the UK and registration for a NINo in the MWS resulting from this feasibility research has also been used to form assumptions in the improved methods for migration and population statistics.

The identification of internal postcode moves by linking of successive MWS extracts has allowed initial comparisons with NHSCR moves data. Despite initial concern that MWS address data may not be regularly updated, the volume of postcode moves identified is encouraging, particularly in London, and further supports inclusion of these data in methodologies and quality assurance of migration and population estimates. The MWS can be used to increase understanding of migrant flows, especially in London. Further research is underway to understand better patterns of migrant movement compared to other sources of information on migrant flows, and assess the potential uses of this information in the local distributions of these migrants. 
Although these data cannot provide information about length of stay in the UK or total coverage of this population group, linkage with other administrative sources could provide valuable supplementary information.

Feasibility work on linking MWS data with patient registration data is currently underway, and will indicate whether MWS data can be successfully linked with other non-DWP sources without a common unique identifier. The findings from this testing will be reported at a later date.

The further research outlined will help to increase understanding of seasonality effects in distributions, internal moves of overseas nationals and the lag between arrival in the UK and NINo registration. The findings from this research will clarify the role that MWS data can play in improving long and short term migration methodologies and statistics.

\section{Key points}

- Initial feasibility studies indicate that anonymised MWS data are potentially useful in improving migration and population statistics

- Internal migration estimation could potentially be improved through linking of successive extracts

- Internal migration estimation methods could also be informed by information on the lag between arrival and registration

- Geographic and demographic distributions from the MWS have the potential to improve the local distribution of international migration estimates

- Further research is underway to assess potential benefits of the MWS, including linking to other data sources.

\section{Acknowledgements}

The authors are grateful for the collaboration and support of colleagues in HM Revenue and Customs (HMRC) and the Department for Work and Pensions (DWP), and also to members of the ONS Administrative Data Development team for their data access and quality work, which is summarised in the paper. The authors would also like to thank the anonymous reviewers for their comments.

\section{References}

1 Office for National Statistics (2006) Report of the Inter-departmental Task Force on Migration Statistics. Available at: www.statistics.gov.uk/STATBASE/Product.asp?vlnk=14731

2 House of Commons Treasury Committee (2008) 'Counting the Population', Eleventh Report of Sessions 2007-08, The Stationery Office, London. Available at:

www.parliament.the-stationery-office.co.uk/pa/cm200708/cmselect/cmtreasy/183/18302.htm 
3 Office for National Statistics (2009) 'Interim report on the potential use of Department for Work and Pensions data to improve population and migration statistics'. Available at:

www.ons.gov.uk/about-statistics/methodology-and-quality/imps/updates-reports/historicalupdates-reports/updates-reports-09/index.html

4 Office for National Statistics (2009) 'Feasibility report on the potential use of record level Migrant Workers Scan data to improve migration and population statistics'. Available at: www.ons.gov.uk/about-statistics/methodology-and-quality/imps/updates-reports/historicalupdates-reports/updates-reports-09/index.html

5 See: http://research.dwp.gov.uk/asd/tabtool.asp

6 Office for National Statistics (2007) Research Report on Short-term Migration, available at: www.statistics.gov.uk/about/data/methodology/specific/population/future/imps/updates/ downloads/STM_Research_Report.pdf

7 In the MWS gender is recorded as 'Male', 'Female/Married' or 'Female/Other', with female marital status based on the title given at application interview. There is no requirement to report subsequent marriage or divorce.

8 A8 countries are: Czech Republic, Estonia, Hungary, Latvia, Lithuania, Poland, Slovakia and Slovenia. These countries gained accession to the European Union in May 2004.

9 www.ons.gov.uk/about-statistics/methodology-and-quality/imps/index.html 